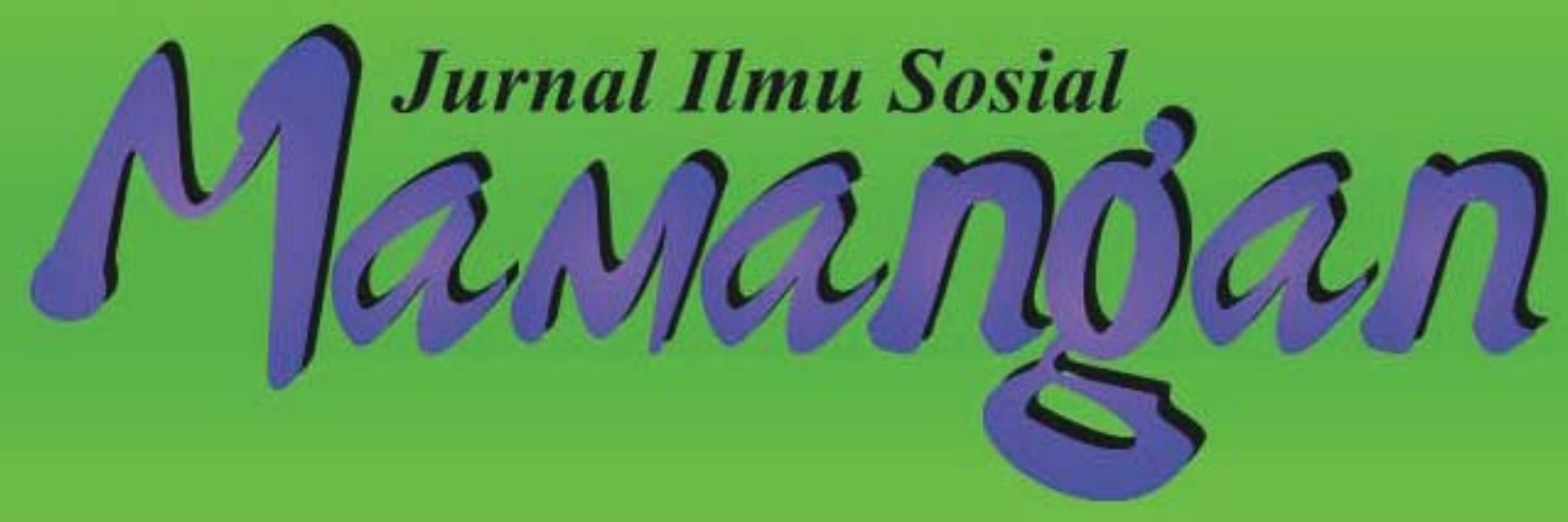

Beberapa Hipotesis Tentang Eksklusi Sosial di Indonesia Robert M.Z. Lawang

Dapatkah Indonesia Bebas Dari Kutukan Kolonial?

Refleksi Kritis Atas MP3EI

Noer Fauzi Rachman \& Dian Yanuardy

Rontoknya Dominasi Negara di Tambang Batu Bara Ombilin Sawahlunto

Zaiyardam Zubir \& Zulqayyim

Protes Korban Bencana; Studi Konflik Penanggulangan Bencana di Pasar Raya Padang

Firdaus

Peran Perempuan dalam Resolusi Konflik Rehabilitasi dan Rekonstruksi Pasar Raya Padang Ira Ariesta

Resolusi Konflik Berbasis Adat; Studi Resolusi Konflik Harta Pusaka Tinggi di Nagari Gantuang Ciri, Kab. Solok, Sumatera Barat

Yuhelna

Nelayan Vs Rentenir; Studi Ketergantungan Nelayan terhadap Rentenir pada Masyarakat Pesisir Delmira Syafrini 


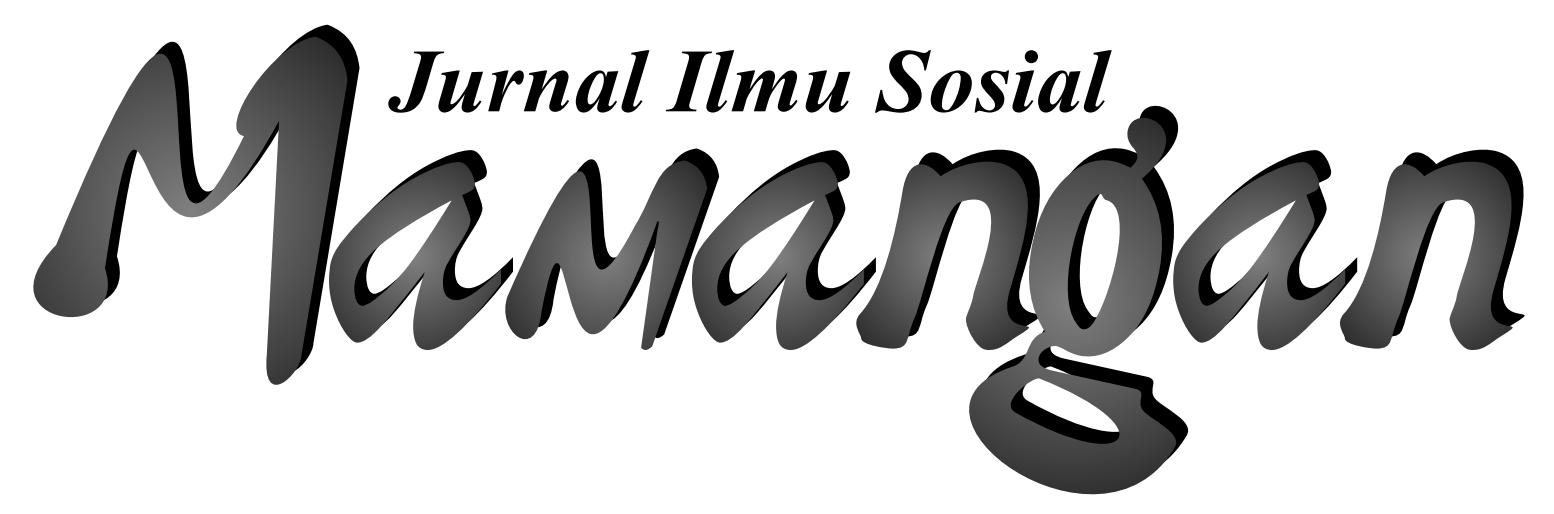




\section{Mitra Bestari}

Prof. Dr. Afrizal, MA. (FISIP, Unand Padang)

Prof. Dr. Badaruddin, M. Si. (FISIP, USU Medan)

Dr. A. Latief Wiyata, M. Si. (Universitas Jember, Jember)

Dr. Fikarwin Zuska, M. Si. (FISIP, USU Medan)

Nurus Shalihin, M. Si., Ph.D. (Fak. Ushuluddin IAIN Imam Bonjol Padang)

Dr. Semiarto A. Purwanto, M. Si. (FISIP, UI Jakarta)

Dr. Wahyu Wibowo, M. Si. (Universitas Nasional, Jakarta)

\section{Dewan Redaksi}

Dr. Zusmelia, M. Si.

Dr. Maihasni, M. Si.

Firdaus, S. Sos., M. Si.

\section{Pemimpin Redaksi/Editor}

Firdaus, S. Sos., M. Si.

\section{Anggota Redaksi}

Dian Kurnia Anggreta, S. Sos., M. Si.

Rinel Fitlayeni, S. Sos., MA.

Rio Tutri, M. Si

Sri Rahayu, M. Pd

Surya Prahara, SH,. MH.

Yuhelna, MA.

ISSN: 2301-8496

viii +81 halaman, $21 \times 29 \mathrm{~cm}$

\section{Alamat Redaksi:}

Laboratorium Program Studi Pendidikan Sosiologi, STKIP PGRI Sumbar Kampus STKIP PGRI, Jl. Gunung Pangilun, Padang, Sumatera Barat

Email: redaksimamangan@yahoo.com \& daus_gila@yahoo.com

\section{Penerbit:}

Laboratorium Program Studi Pendidikan Sosiologi, STKIP PGRI Sumbar

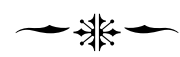




\section{PENGANTAR REDAKSI}

K onflik dalam masyarakat merupakan keniscayaan. Ia akan terus menjadi bagian dalam dinamika kemasyarakatan dan mengejawantah dalam berbagai bentuk yang secara garis bersar dikategorikan sebagai bentuk laten dan bentuk manifest. Pola dan bentuk konflik juga terus mengalami perkembangan sesuai dengan tingkat perkembangan masyarakat dimana konflik tersebut ada. Pola dan bentuk itu, mulai dari yang sederhana hingga yang paling 'canggih' dan bahkan disengaja ada untuk kepentingan tertentu oleh kelompok tertentu.

Meskipun para penganut fungsionalisme meganggap bahwa konflik dalam kehidupan sosial adalah abnormal (Johnson, 1994:161), namun konflik di lain kesempatan merupakan fakta sosial yang bisa fungsional bagi struktur tertentu selama ia dikelola dengan baik. Maka konflik kemudian di beberapa kesempatan juga dibutuhkan untuk kepentingan-kepentingan tertentu. Sehingga dengan demikian, adakalanya konflik mengikuti polanya sendiri dan adakalanya seirama dengan perkembangan masyarakat.

Menyadari bahwa perkembangan masyarakat terus melaju ke bentuk yang lebih kompleks, dan asumsi bahwa konflik juga akan kompleks sesuai dengan perkembangan kompleksitas masyarakat, Mamangan Edisi II yang ada di tangan pembaca ini mengambil konflik sebagai tema umum. Dalam edisi ini konflik dilihat oleh penulis dalam berbagai dimensi melalui berbagai pendekatan, baik secara teoritis maupun empiris melalui studi lapangan. Beberapa pakar di bisangnya telah menyumbang dalam dalam edisi kedua ini.

Tulisan pertama disumbangkan oleh Prof. Robert Lawang yang mendiskusikan konsep eksklusi sosial dalam konteks sosial, ekonomi dan politik. Tiga ranah ini menurut Lawang dikuasai arus utama (main stream) yang tidak mudah dimasuki oleh kelompok sosial tertentu dalam masyarakat paling bawah (underclass), sehingga mereka mengalami deprivasi. Selain itu, Lawang juga menyebut adanya perbedaan pandangan dan cara menjelaskan gejala sosial yang terkait eksklusi sosial. Meskipun konsep eksklusi sosial adalah konsep Barat, namun di Indonesia menurut Lawang, eksklusi sosial terjadi dalam berbagai struktur sosial masyarakat, baik di perkotaan maupun di pedesaan. 
Tulisan kedua disumbangkan oleh Noer Fauzi Rachman dan Dian Yanuardy yang mengupas secara kritis MP3EI. Dalam tulisannya, Fauzi dan Dian mempreteli skema MP3EI dan menyebutnya sebagai bagian dari upaya untuk memperdalam integrasi tanah air Indonesia ke dalam zona perdagangan bebas ASEAN dan Asia Timur. menurut mereka MP3EI pada pokoknya bertumpu pada upaya untuk melakukan reorganisasi ruang dalam rangka memperlancar interaksi dan aliran kapital, barang dan tenaga kerja untuk aktivitas produksi-konsumsi. Skema MP3EI dalam pola pemberian lisensi pada perusahaan untuk mengeksploitasi Sumber daya Alam menurutnya tidak jauh berbeda dengan kebijakan pemerintah kolonial Belanda sejak 1870, yang menempatkan Indonesia sebagai tempat produksi komoditas global.

Tulisan ketiga disumbangkan oleh Zayardam Zuber dan Zulqayim tentang rontoknya dominasi negara di Tambang Batubara Omblin, Sawahlunto. Zayardam dan Zulqayim dalam tulisannya mengemas sejarah beralihnya tambang di Kota Sawahlunto dari tangan perusahaan ke tangan rakyat yang selama puluhan tahun hanya menjadi penonton di arena tambang. Proses peralihan tersebut menurut Zayardan dan Zulqayim antara lain dilatari oleh penguasaan terhadap lahan di sekitar tambang yang dikuasi oleh dua kelompok, yaitu masyarakat adat dan pemerintah daerah. Selain itu, menurunnya aktivitas tambang PT. BA-UPO selaku BUMN yang kemudian menyerahkan pengurusan tambang kepada Pemda setempat juga menjadi bagian dari latar rontokya dominasi negara.

Tulisan keempat disumbangkan oleh Firdaus yang menguraikan protes korban bencana dalam proses rehabilitasi dan rekonstruksi di Pasar Raya Padang. Firdaus menyebutkan faktor penyebab munculnya protes adalah kebijakan pembangunan yang tidak partisipatif dan merugikan pedagang yang merupakan korban bencana. Kebijakan itu dibuat oleh pemerintah melalui mekanisme yang tidak sesuai dengan aturan yang ada. Protes yang dilakukan oleh korban bencana dilakukan dengan berbagai strategi, mulai dari strategi konfrontasi hingga negosiasi.

Tulisan kelima disumbangkan oleh Ira Ariesta yang mengulas peran perempuan dalam resolusi konflik Pasar Raya Padang. Ulasan Ira 'nyambung' dengan tulisan Firdaus sebelumnya. Jika Firdaus lebih menekankan pembahasan tentang penyebab dan strategi protes, maka Ira lebih menekankan pada resolusi konflik. Resolusi konflik yang dibahas Ira lebih fokus lagi pada peran perempuan. Menurut Ira, peran perempuan dalam proses resolusi konflik di Pasar Raya dilakukan oleh empat aktor utama, yaitu perempuan dari instansi pemerintah, perempuan aktivis LSM (PBHI Sumbar), perempuan aktivis mahasiswa dan perempuan pedagang. Keempat kelompok memainkan peran yang berbeda dalam resolusi konflik, mulai dari aksi massa hingga kegiatan advokasi terorganisir.

Tulisan keenam disumbangkan oleh Yuhelna yang membahas tentang mekanisme penyelesaian konflik harta pusaka tinggi secara adat di Minangkabau. Penyelesaian konflik harta pusaka tinggi di Minangkabau dilihat di nagari Gantuang Ciri. Resolusi konflik dilakukan pada 3 tingkatan. Tingkatan pertama resolusi konflik dilakukan di tingkat suku dengan melibatkan pangulu suku. Tingkat kedua resolusi konflik dilakukan pada tingkat yang lebih luas, yaitu pada institusi Tigo Niniak atau Ampek Niniak. Pada tingkat ini, resolusi konflik difasilitasi oleh niniak mamak masing-masing suku atau kaum yang berkonflik. Pada tingkat ketiga resolusi konflik dilakukan di lembaga adat Kerapatan Adat Nagari (KAN). Resolusi konflik pada tingkat ini difasilitasi oleh pengurus KAN yang merupakan perwakilan dari semua suku yang ada dalam nagari.

Tulisan terakhir, disumbangkan oleh Delmira Syafrini yang menganalisis ketergantungan nelayan dengan tengkulak di wilayah pesisir. Delmira melihat ketergantungan nelayan terhadap rentenir sebagai fenomena yang dilematis. Di satu sisi, nelayan mendapat kemudahan mengakses 
modal, di sisi lain nelayan dirugikan dengan suku bunga yang tinggi. Sementara, lembaga keuangan seperti Bank belum mampu menjadi katup penyelamat karena mekanisme rungguhan yang disyaratkan lembaga ini tidak terjangkau oleh nelayan. Di bagian akhir, Delmira menawarkan pemberdayaan sebagai solusi untuk memutus ketergantungan nelayan terhadap rentenir.

Demikianlah tulisan pada edisi ini, dan kepada para penyumbang tulisan pada edisi ini redaksi mengucapkan terima kasih atas karya intelektual dan buah pemikiran mereka, dan kepada para pembaca, redaksi mengucapkan selamat membaca. 



\section{DAFTAR ISI}

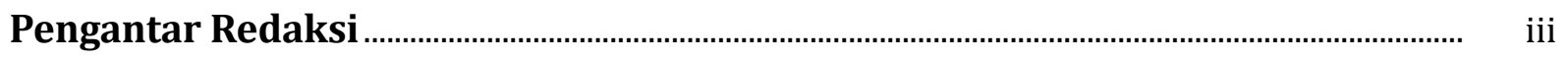

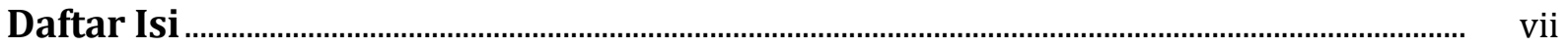

Beberapa Hipotesis Tentang Eksklusi Sosial di Indonesia

Robert M.Z. Lawang

Dapatkah Indonesia Bebas Dari Kutukan Kolonial?

Refleksi Kritis Atas MP3EI

Noer Fauzi Rachman \& Dian Yanuardy

Rontoknya Dominasi Negara di Tambang Batu Bara Ombilin Sawahlunto

Zaiyardam Zubir \& Zulqayyim

Protes Korban Bencana; Studi Konflik Penanggulangan Bencana di

Pasar Raya Padang

Firdaus

Peran Perempuan dalam Resolusi Konflik Rehabilitasi dan Rekonstruksi

Pasar Raya Padang

Ira Ariesta

Resolusi Konflik Berbasis Adat; Studi Resolusi Konflik Harta Pusaka Tinggi di Nagari Gantuang Ciri, Kab. Solok, Sumatera Barat

Yuhelna

Nelayan Vs Rentenir; Studi Ketergantungan Nelayan terhadap Rentenir pada Masyarakat Pesisir

Delmira Syafrini .

Profil Penulis. 



\title{
RONTOKNYA DOMINASI NEGARA DI TAMBANG BATU BARA OMBILIN SAWAHLUNTO
}

\author{
Zaiyardam Zubir \& Zulqayyim \\ (Dosen Fakultas Ilmu Budaya Universitas Andalas. Mahasiswa Doktoral \\ Universitas Gadjah Mada Yogyakarta) \\ 一非—
}

\begin{abstract}
In various place at Indonesia, the problem concerning mine workings with people potentially trigger some conflict. This conflict will be manifest and make the corporate collapse. PT. Batubara Ombilin is not an exception, that have been in the prosperity from colonial era till Orde Baru era is also fall down. The fall of government enterprises followed by the influx of people in mining activity, which is known by a variety of forms such tambang rakyat, tambang tanpa izin and tambang liar.

Since reformation era, there is a lot of change in mining world. People who only been a spectator become miner. The mining district claimed by the corporate, step by step become tambang rakyat. Conflicts can't be avoid, lots occur at mining concession. Mining corporate can't confront the amount of people power, with the result that tambang rakyat spread their invasion into corporate mine district. PT. Batubara Ombilin is one of the mining that in the end taken by people.
\end{abstract}

Key words: Tambang, Dominasi, Negara, Rakyat dan konflik

\section{Pendahuluan}

Sekali tempo, jika melewati wilayah kota Sawahlunto dan sekitarnya, kita akan disuguhkan dengan pemandangan berupa puluhan kolam kecil yang tersebar di wilayah itu. Janganlah bersenang hati dulu melihat puluhan danau itu, karena kolam-kolam itu bukan bagian dari keindahan alam, tetapi justru merupakan malapetaka yang tengah dihadapi kota itu. Betapa tidak, asal muasal kolam itu adalah bekas tambang batubara yang dibiarkan begitu saja dan tidak direklamasi kembali, sehingga menjadi kolam-kolam. Hal ini terjadi terutama sejak berkembangnya tambang in-konvensional di kota itu (Zubir \& Zulqayyim, 2006).

Sawahlunto telah menjadi kota tambang sejak tahun 1891 lalu (Erwiza, 2005) di bawah bendera PT. Batubara Ombilin. Kota ini pernah mengalami masa-masa kejayaan. Namun, sejak reformasi aktivitas tambang milik PT. Batubara Ombilin mulai memperlihatkan grafik menurun. Hal ini disebabkan oleh keterlibatan pengusaha dan masyarakat dalam tambang, sehingga usaha perubahan milik negara ini sedikit demi 
sedikit hilang kedigdayaannya. Persoalan persaingan berebut lahan dan pemasaran, membuat perusahan berumur lebih satu abad itu mengalami kerugian. Puncaknya adalah ketika PT. Minang Malindo, sebuah perusahaan yang disinyalir milik anak Gubernur dan anggota DPRD Tk. I Sumatera Barat ikut dalam bisnis tambang rakyat di Sawahlunto (Erman, 2004).

Gejolak yang terjadi di perusahaan tambang merupakan gejala yang terjadi sepanjang sejarah perusahaan itu berdiri. Aktor utama dalam gejolak tambang adalah buruh yang bekerja pada tambang batu bara Ombilin (Zubir, 2006). Sementrara itu, masyarakat luar tambang yang tidak memiliki interaksi dengan tambang, sepanjang sejarah tambang itu tidak mengalami dinamika yang berarti, yang menjadikan masyarakat turut bergolak. Dapat dikatakan bahwa masyarakat sekitar taambang merupakan bagian yang terpisah secara sosial, ekonomi dan politik dengan tambang, sehingga mereka hanyalah penonton saja dari dinamika yang berlangsung di dalamnya.

Barulah di era reformasi, Masyarakat yang selama ini hanya jadi penonton, kemudian baru masuk dan terlibat dalam bisnis tambang. Safarudin, seorang lelaki tua penduduk asli Sungai Durian, Sawahlunto menyatakan bahwa sejak ia pandai berjalan, ia telah melihat dan menginjak batu bara di jalanan di sekitar rumahnya. Namun, karena ia bukan bekerja di PT. Batubara Ombilin, ia tak pernah merasakan "manisnya uang" dari batu yang terdapat di tanah leluhurnya itu. Batu bara yang sangat banyak terkandung di sekitar tempat tinggalnya hanya dapat ia lihat-lihat saja. Lebih dari itu, tidak bisa mereka lakukan sebab pengambilan batu bara diaggap sebagai pencuri dan bisa masuk penjara (Wawancara informan laki-laki).

Baik Safarudin maupun ribuan masyarakat Sawahlunto lainnya memang hanya jadi penonton saja. Mereka hanya melihat kememawahan yang ditampilkan karyawan tambang. Mobil-mobil dengan plat BA $x x x$ RO, merupakan simbol dari penjajahan ekonomi oleh negara dan rakyat tidak mandapatkan apapun juga, kecuali abu-abu dari asap mobil tambang, yang berkeliaran di sekitar hunian mereka. Barulah, sejak reformasi, melalui aktivitas ekonomi tambang rakyat berlangsung sejak 1999, masyarakat Sawahlunto baru bisa merasakan manisnya rasa uang dari batu bara yang terdapat di tanah yang terdapat di tanah ulayat mereka (Wawancara informan laki-laki).

Tulisan ini membahas rontoknya dominasi negara pada perusahaan PT. Batubara Ombilin. Pemikiran dasar pengambilan perusahaan ini disebabkan pada periode sebelumnya terutama masa Orde Baru- dominasi negara pada perusahaan ini sangat dominan. Namun sejak era reformasi, dominasi negara berkurang sampai kemudian tambang dikuasai oleh tambang rakyat. Jumlah tambang rakyat mencapai puluhan. Beberapa pokok persoalan yang akan dibahas dalam tulisan ini adalah mengenai latar belakang dominasi negara pada PT. Batubara Ombilin Sawahlunto, faktor-faktor yang menyebabkan mundurnya PT. Batubara Ombilin Sawahlunto, penyebab keresahan sosial selama berlangsungnya tambang rakyat dan keberhasilan peningkatan ekonomi rakyat selama tambang rakyat berlangsung.

\section{PT. BA-UPO dan Kemundurannya}

PT. Tambang Batubara Bukit Asam (PT. BA) merupakan salah satu Badan Usaha Milik Negara pada masa pemerintahan Orde Baru. Unit Pertambangan Ombilin (UPO) dari PT. Bukit Asam telah meraih banyak keuntungan hingga tahun 1998. Pada tahun itu, produksi batubara Ombilin mencapai 99\% dari yang direncanakan (Haluan, 1998). Menjelang berakhirnya Orde Baru dan setelah reformasi, aktivitas tambang PT. BA-UPO selaku BUMN mulai menurun. Pada tahun 2002, kegiatan tambang terbuka PT. BAUPO di area Pasca Tambang Terbuka di daerah Kandi dan Tanah Hitam secara resmi dihentikan, 
terhitung mulai tanggal 31 Desember 2002 melalui Surat kepala teknik PT. BA-UPO Nomor 287/02.10.00000002/V-03 tanggal 6 Mei 2003.

Disamping PT. Bukit Asam, tanah di lokasi Kuasa Pertambangan (KP) PT. Bukit Asam juga dikuasai oleh dua kelompok lain, yakni masyarakat setempat dan Pemerintah Daerah. Untuk Pemda dan masyarakat, PT. Bukit Asam menyediakan Surat Izin Pemakaian Tanah (SIPT). Penggunaan SIPT untuk penggunaan tanah oleh masyarakat berlangsung untuk jangka waktu yang cukup lama sehingga area dengan SIPT telah menjadi daerah pemukiman. Hingga tahun 2002, SIPT yang telah dikeluarkan PT. BA telah mencapai 1.852 SIPT di 14 desa (Pemerintah Kota Sawahlunto, 2004:8).

Namun surat izin ini berhenti dikeluarkan sejak tahun 2002 atas permintaan Pemerintah Daerah (Pemerintah Kota Sawahlunto, 2004:4). Menurut laporan yang disusun oleh Tim Inventarisasi dan Penertiban Tanah Kuasa Pertambangan PT. Bukit Asam (Persero)- UPO, Pemerintah Kota Sawahlunto yang berjudul "Laporan Kegiatan Pendataan dan Penertiban Tanah Dalam Kuasa Pertambangan PT. Bukit Asam (Persero)- UPO" tahun 2004, perubahan situasi ini menyebabkan masalah sebagai berikut:

1. Sulitnya melakukan penertiban terhadap pemanfaatan tanah yang berada dalam lokasi Kuasa Pertambangan.

2. Tidak adanya kepastian hukum terhadap status tanah dalam Kuasa Pertambangan PT. BA-UPO yang telah lama dikuasai oleh masyarakat.

3. Banyak masyarakat yang telah memindahtangankan penguasaan tanah dalam Kuasa Pertambangan PT. BA-UPO tanpa seizin pihak PT. BA-UPO.

4. Banyak masyarakat yang mendirikan bangunan dalam kuasa PT BA-UPO tidak memiliki Izin Mendirikan Bangunan (IMB) karena tidak jelas status kepemilikan tanahnya.
Pada tahun 2002, PT. BA-UPO menghentikan aktivitas pertambangan luarnya. Hal ini berpengaruh terhadap perekonomian kota dan masyarakat. Terhadap masyarakat, kerugian dirasakan terutama dalam hal hilangnya lapangan pekerjaan bagi masyarakat, dari ribuan karyawan, menurun menjadi 422 orang di tahun 2002 (Media Indonesia, 2002). Kemudian pada tahun 2004, perusahaan ini secara resmi menyerahkan pengurusan pertambangan ke pemerintah kota Sawahlunto melalui surat Perjanjian dan Kesepakatan antara PT. Tambang Batubara Bukit Asam (PT. BA) dengan Pemerintah Kota Sawahlunto, No. Nomor. 0608. 04/2400000002/11-2004. Poin utama dari kesepakatan ini dapat dirangkum sebagai berikut:

1. PT. BA-UPO sepakat untuk menyerahkan area pasca Tambang Terbuka di daerah Kandi dan Tanah Hitam seluas 394,45 Ha.

2. Pemerintah Kota Sawahlunto sepakat untuk mereklamasi area bekas tambang membangun Resort Wisata dan Sarana Olahraga seperti Lapangan Pacuan Kuda, Lapangan Arena Motor Cross, Sircuit Road Race, Pembuatan Danau Wisata dan Sarana Prasarana Lainnya, dengan sumber dana reklamasi dari PT. BA-UPO.

Meskipun pada akhirnya BUMN ini mengakhiri kegiatan tambang terbukanya di daerah tersebut, dampak nyata transformasi ini bagi masyarakat masih merupakan tanda tanya. Pertanyaan terbesarnya adalah, sejauh mana masyarakat dapat terlibat langsung dalam kegiatan perekonomian dan menghasilkan keuntungan bagi mereka. Dalam laporan Pemerintah Kota Sawahlunto yang menjelaskan adanya SIPT memang terlihat seolah masyarakat memiliki hak untuk mencari penghidupan di daerah tambang. Bahkan dalam penjelasannya mengenai SIPT, disebutkan bahwa konsekuensi dari hubungan yang tidak jelas adalah masyarakat yang bertindak melanggar hukum. Namun, pihak keamanan tidak memiliki kekuatan dan 
keberanian untuk menindaknya, sehingga serupa tanah tak bertuan saja. Kelompok atau orang-orang yang memiliki keberanian dan kenekatanlah yang bisa bermain bara di wilayah tambang Sawahlunto.

\section{Rakyat dalam Pertambangan: Peti dan Masalah Tanah Ulayat}

\section{Masalah PETI}

Pertambangan tanpa Ijin (PETI) merupakan aktivitas tambang yang dilakukan tanpa izin pemerintah berdasarkan UndangUndang No. 11 tahun 1967. Memasuki tahun 1996, pertambangan tanpa ijin (PETI) mulai marak terjadi di area pertambangan terbuka PT. Bukit Asam. Mulai terjadinya PETI pada periode ini dimungkinkan oleh berbagai faktor. Menurut laporan Pemerintah Kota berjudul tentang Penataan KP Eksploitasi Ombilin dan Upaya Penertiban Aktivitas PETI di Kota Sawahlunto sampai akhir tahun 2006", kemunculan PETI di tahun ini merupakan akibat dari ketidakpuasan masyarakat sekitar atas pemakaian tanah ulayat sebagai lokasi tambang. Dengan status area pertambangan sebagai tanah ulayat, penduduk sekitar merasa bahwa sudah seharusnya PT. Bukit Asam membayar ganti rugi kepada masyarakat. Sementara itu, hingga tahun 1996 tersebut, tidak ada ganti rugi yang dibayarkan kepada mereka. Pada laporan ini disebutkan, $60 \%$ dari wilayah kerja penambangan di Sawahlunto pada kenyataannya merupakan wilayah tanah ulayat yang belum diganti rugi. Meskipun sempat berhenti di awal tahun 1998, praktek PETI mulai terjadi lagi. Sempat terhentinya praktek ini merupakan dampak dari kesepakatan yang dibangun perusahaan dengan para pemilik tanah ulayat.

PETI dianggap meresahkan karena beberapa hal. Bagi PT. Bukit Asam dan pemerintah, tentunya tindakan ini dianggap melanggar hukum dan mengganggu pertambangan yang resmi. Di samping itu, PETI seringkali dilakukan di lokasi yang berbahaya seperti di banier pillar atau kaki pengaman tambang bawah tanah (Mimbar Minang, 2003). Aktivitas PETI disana dapat membahayakan keselamatan penduduk sekitar dan lingkungan (Mimbar Minang, 2003). Fakta yang perlu diperhatikan mengenai PETI adalah, seringkali PETI bukan dilakukan oleh rakyat jelata yang tidak memiliki modal, seperti yang akan diuraikan dalam satu sub-bab dalam tulisan ini.

Upaya untuk menindak PETI telah dilakukan dari tahun ke tahun dengan berbagai pendekatan. Antara lain pendekatan ini dilakukan dengan cara:

\section{a. razia}

b. penyuluhan

c. tindakan represif

d. penerbitan perizinan

e. pembatasan tonase kendaraan

f. pembuataan perda

g. penciutan KP oleh UPO

h. pembentukan Dinas Pertambangan

i. pengalihan USAHA PETI ke sektor lainnya

j. pengaturan niaga batubara (Sumber: Laporan Penataan Eksploitasi Ombilin dan Upaya Penertiban Aktivitas PETI di Kota Sawahlunto)

Bagaimanapunjuga, upaya menurunkan aktivitas PETI ini tidak selalu efektif. Tak jarang, pihak seperti Polri dan TNI justru mendukung kegiatan PETI (Mimbar Minang, 2003).

Di sisi lain dari PETI, perlu dipahami bahwa terdapat isu tanah ulayat di daerah pertambangan PT. BA-UPO. Permasalahan tanah ulayat menciptakan sisi lain dari isu daerah pertambangan. Tanah ulayat dan masyarakat yang mengklaim hak dengan status tanah ulayat menyebabkan pembahasan tidak lagi semata soal masyarakat yang menambang tanpa ijin. Justru, masyarakat disini juga memahami tanahnya sebagai haknya. 


\section{Tanah Ulayat di Area Pertambangan Batubara}

Bagaimanakah sebenarnya status kepemilikan tanah oleh PT. BA-UPO, dan bagaimana kepemilikan tanah oleh masyarakat? Menurut laporan Pemerintah Kota Sawahlunto tahun 2004, kepemilikan tanah di Kota Sawahlunto secara keseluruhan dipegang oleh berbagai pihak. PT BA-UPO memiliki 9,020 Ha, dan hanya sebagian kecil dari tanah tersebut yang ada sertifikatnya. Tanah yang memiliki sertifikat adalah tanah dimana bangunan asset PT. BA-UPo dibangun, sementara sisanya dimiliki melalui Kuasa Penambangan (KP). Dalam laporan ini dijelaskan bahwa seiring dengan menurunnya aktivitas tambang PT. BA-UPO sekitar tahun 2002, mulai banyak pihak yang mengklaim kepemilikan di area pasca tambang.

Di Minangkabau, terdapat klaim kepemilikan tanah berbasis tanah ulayat. Tanah di wilayah Sumatera Barat pada umumnya merupakan tanah ulayat, yakni tanah milik kaum. Pada masa penjajahan dan pemerintahan Orde Baru, tanah ulayat diserahkan untuk diolah oleh penguasa. Argumen 'tanah ulayat' selalu bertabrakan dengan hukum tanah negara, sehingga hampir selalu terjadi persinggungan antara masyarakat dengan negara ataupun dengan pengusaha dalam hal klaim tanah.

Tanah ulayat di Minangkabau berasal dari sistem Nagari, dimana Nagari dapat dikelompokkan ke dalam hukum adat yang otonom. Di dalam suatu Nagari terdapat Undang-undang Nagari, yang ruang lingkup berlakunya sebatas lingkungan nagari yang berstatus otonom dan tidak memuat pasal seperti halnya undang-undang dalam pengertian yuridis (Wawan, 2007: 8). Nagari disini memiliki sifat "masyarakat hukum adat", dimana masyarakat menempati suatu daerah tertentu, memiliki pemimpinnya sendiri dan memiliki norma-norma dan aturannya sendiri yang berbeda dari daerah lain, dan mereka taati bersama (Kurnia Wawan, 2007:2). Persoalannya adalah pihak perusahaan mengabaikan hukum adat ini, sehingga secara sepihak mereka mengkalaim tanah yang ada milik perusahaan. Pada kenyataannnya yang terjadi adalah peramapasan oleh perusahaan.

Dengan memahami bahwa Nagari memiliki normanya sendiri, ia tidak dapat begitu saja diatur dengan hukum di luarnya. Hal ini menimbulkan masalah ketika berhadapan dengan hukum Negara. Menurut hukum adat yang berlaku, tanah ulayat kaum ini merupakan tanah hak milik. Oleh karena itu, pihak di luar yang dilingkupi oleh tanah ulayat tidak bisa mendapat hak milik, atau hak atas tanah ulayat tidak bisa dipindahkan kecuali ada kondisi darurat yang memaksa hal ini untuk dilakukan (Suwarno, 2007:10).

Ha katas tanah masyarakat hukum adat dilindungi oleh Negara melalui UU No. 5 tahun 1960, yang disebut juga UndangUndang Pokok Agraria (UUPA), sebagai interpretasi atas konsep hak Negara pada pasal 33 ayat 3 UUD 1945. Dalam Pasal 3 UUPA dinyatakan bahwa hak-hak ulayat dan hak-hak serupa itu diakui oleh Negara. Walaupun telah diakui oleh Negara, hingga saat ini belum diatur penerapannya melalui peraturan perundang-undangan yang spesifik (Kurnia Wawan, 2007:18). Pengaturan ini memang dibutuhkan, namun jika mengacu pada aturan adat, maka persoalan seperti ini dari awal bisa lebih mudah diselesaikan.

\section{Contoh kasus 1:}

Pengajuan sertifikat tanah oleh Syafei Rajo Pahlawan, tahun 2007

Menurut PT. BA-UPO, berdasarkan tanah bekas lahan pertambangan terbuka telah diserahkan kepada pemerintah kota 
Sawahlunto, oleh karenanya, masyarakat umum tidak berhak atas kepemilikan tanah. Di sisi lain, masyarakat pada umumnya melihat tanah tersebut adalah tanah ulayat. Pada kasus yang dialami seorang warga bernama Syafei Rajo Pahlawan, upaya untuk mendapatkan hak atas tanah ulayat terhambat oleh PT. BAUPO dan karenanya berhak untuk mengajukan sertifikat kepemilikan. Hal ini terlihat dari dokumen-dokumen yang digunakan untuk mendukung permohonannya, seperti:

1. Surat pernyataan penguasaan fisik bidang tanah (Sporadik) a.n. Syafei Rajo Pahlawan yang dibenarkan oleh mamak kepala waris dan Penghulu Suku dan Diketahui oleh Ninik Mamak IV Jinih, KAN dan kepala Desa Setempat

2. Surat pernyataan persetujuan Anggota Kaum yang diketahui oleh Ketua KAN, serta kepala desa setempat

3. Surat keterangan Kepala Desa Kolok Mudik

4. Silsilah Ranji Keturunan Kaum Syafei Rajo Pahlawan menurut Adar Minangkabau (Sumber: Surat permohonan pengakuan hak milik dari Syafei Rajo Pahlawan ke Kantor Pertanahan Kota Sawahlunto 8 Maret 2007)

Penggunaan dokumen pendukung yang berkaitan dengan kaum dan suku dalam memproses permohonan pengakuan atas hak milik tanah tersebut memperlihatkan bagaimana masyarakat dengan baik bahwa memahami tanah sebagai tanah ulayat milik kaum mereka. Permohonan pengakuan hak milik atas nama Syafei Rajo Pahlawan sementara itu digugat oleh Unit Pertambangan Ombilin Sawahlunto melalui surat yang terbit dua tahun setelahnya yang menyatakan bahwa:

1. Lahan tersebut diatas adalah areal paska Tambang Terbuka milik PT Bukit Asam (Persero) Tbk.
2. Berdasarkan kesepakatan antara PT Bukit (Persero) Tbk dengan Pemerintah Kota Sawahlunto Nomor. 0608.04/2400000002/11-2004 dan Nomor 180/lahan/Huk-Org/2004, bahwa areal pasca tambang terbuka di Daerah Kandi dan Tanah Hitam seluas 393,45 Ha diserahkan pengelolaannya ke pemerintah Kota. (Sumber: Surat Gugatan GM Unit Pertambangan Ombilin Sawahlunto tanggal 13 April 2009)

Dalam surat Walikota Sawahlunto Ir. H. Amran Nur yang ditujukan kepada Kepala Kantor BPN, pemerintah meminta kepada BPN untuk tidak memproses penertiban hak atas tanah (sertifikat) yang diusulkan di lokasi tersebut "untuk menghindari tumpang tindih kepemilikan lahan di lokasi dimaksud). Di samping itu, dengan bantuan sebuah Kantor Hukum, PT. Bukit Asam menuntut haknya. Salah satu argumennya adalah: "Karena lahan tersebut masih dikuasai oleh PT. Bukit Asam, Kantor Pertanahan Kota Sawahlunto tidak berhak menilai secara sepihak pengajuan permohonan sertifikat tersebut." Dengan argumen tersebut, PT. BA-UPO menuntut Kantor Pertanahan Kota Sawahlunto untuk tidak menerbitkan sertifikat tanah tersebut.

Gugatan PT. BA-UPO in i memperlihatkan bagaimana peraturan mengenai area pertambangan tidak mengikutsertakan logika tanah ulayat di dalamnya. Lebih tepatnya, dengan adanya klaim bahwa lahan yang diperkarakan merupakan miliknya, terlihat bahwa tidak terdapat titik temu antara logika tanah ulayat dan logika pertambangan dari perusahaan dan pemerintah. Dengan kata lain, untuk memahami kasus tanah seperti di atas, tidak cukup dengan semata-mata melihat dari sisi masyarakat, atau semata-mata melihat dari sisi pembuat kebijakan, yakni pihak yang berkuasa. 


\section{Contoh kasus 2:}

Somasi Niniak Mamak Nagari Kubang Kecamatan Lembah Segar Kota Sawahlunto atas perpanjangan pemakaian tanah bekas Kuasa Penambangan PT. BA-UPO

Seperti halnya pada contoh kasus pertama, padacontoh kasusini, masalah berawal dari penyerahan kekuasaan pengelolaan tanah dari PT. Bukit Asam ke pemerintah kota Sawahlunto. Selanjutnya Niniak Mamak Nagari Kubang mempermasalahkan pengabaian peran Niniak Mamak dalam pembuatan keputusan terkait tanah di area pertambangan.

Niniak Mamak Nagari Kubang Kecamatan Lembah Segar Kota Sawahlunto misalnya mempermasalahkan perpanjangan pemakaian tanah bekas KP PT. Bukit Asam serta penjualan penyewaan tanah ke PT. Kereta Api Indonesia (KAI). Dalam kasus ini, Niniak Mamak mengajukan somasi dengan menggunakan prinsip pertanahan di Minangkabau, sebagaimana disebutkan dalam somasinya:

"Berbicara masalah tanah yang merupakan salah satu unsur hak ulayat, warisannya sudah jelas dengan filosofi adat yang mengatakan, "Kok dijua dak dimakan bali, kok digadai, dak dimakan sando", artinya: masalah tanah di Minangkabau pada prinsipnya tidak bisa diperjualbelikan maupun digadaikan atau diborohkan..."

"Orang Minangkabau telah memilih dan menetapkan agamanya yaitu agama Islam. Oleh karena itu apa yang telah digariskan oleh agama dalam AlQur'an, dipakaikan dalam adat. Agama mengajarkan kepada kita bahwa asal mula kejadian manusia yaitu penciptaan Nabi Adam AS dari tanah. Maka berdasarkan itulah pada prinsipnya di Minangkabau, tidak mengenal hak milik atas tanah, yang ada adalah: hak guna bangunanm hak guna usaha, hak pakai dan hak sewa."
Dari kutipan surat somasi pertama di atas tergambar kuatnya pengaruh prinsip agama Islam dan adat dalam membentuk pola kepemilikan tanah di mata masyarakat. Berdasarkan pemahaman akan tanah dengan cara tersebut, Niniak Mamak mempermasalahkan penerbitan surat izin pemakaian tanah oleh PT. Bukit Asam UPO, penyerahan aset yang tidak dimanfaatkan lagi oleh PT. BA-UPO kepada pemerintah kota dan pihak lain tanpa didiskusikan sebelumnya dengan Niniak Mamak.

Di samping itu, dalam somasi keduanya, Niniak Mamak mempertegas hal ini dengan menuliskan:

"Kepada pihak PT BA-UPO kami harapkan:

1. Apabila akan melakukan penambangan dalam KP yang telah diperpanjang oleh Walikota Sawahlunto dalam tanah ulayat Nagari Kubang harus dimusyawarahkan dengan pihak pemegang ulayat dan bersedia memberikan kontribusi untuk kepentingan pembangunan Nagari secara nyata

2. Bagi tanah-tanah bekas penambangan dan sarana pendukung lainnya yang telah dialihfungsikan menjadi daerah pemukiman agar dikembalikan statusnya sebagai ulayat Nagari Kubang."

Dari kedua contoh kasus ini, dapat disimpulkan bahwa prinsip tanah ulayat yang dipegang oleh masyarakat sering bertabrakan dengan proses pemakaian tanah dan sumber dayanya oleh pemerintah dan pihak lain yang memiliki power.

\section{Keterlibatan Pengusaha dalam Tambang}

Semenjak PT. BA-UPO masih aktif, telah banyak perusahaan tambang diluar BUMN 
yang mendapatkan izin untuk menambang batubara di Sawahlunto. Di Sumatera Barat pada umumnya, perusahaan penambang batu bara selain PT BA-UPO telah mendapat izin sejak sebelum reformasi (Haluan, 1998). Dalam laporan berjudul "Penataan KP Eksploitasi Ombilin dan Upaya Penertiban Aktivitas PETI di Kota Sawahlumto sampai akhir tahun 2006", pendataan aktivitas PETI di wilayah perusahaan memperlihatkan banyaknya perusahaan yang mendapat izin di Sawahlunto. Di antaranya adalah CV. Air Mata Emas di Kumanis Atas, PT. Guguk Tinggi Coal di Parambahan, PT. Dasrat Saeana Arang Sejati di Ngalau Cigak, PT. Nusa Alam Lestari di Sapan Dalam dan CV. Tahiti Coal di Sangkar Puyuh. Di samping perusahaan yang mendapat ijin langsung dari PT. BA-UPO, juga terdapat perusahaan yang beroperasi tanpa izin dengan menjadi penadah bagi penambang liar.

PT. Minang Malindo misalnya, Dalam beberapa kasus tidak mengerjakan penambangan atau operasional di lapangan, akan tetapi lebih bersifat penadah dari hasil tambang yang dilakukan oleh masyarakat. Kasus batu bara yang berasal dari penambangan Bukit Bual menjadi contoh proses kerja PT. Minang Malindo ini.

PT. Minang Malindo merupakan perusahaan tambang illegal, namun karena kekuasaan yang bermain, menjadi dilegalkan oleh pemerintah Provinsi Sumatera Barat, terutama melalui Kuasa Penambang (KP) yang dibuat oleh Gubernur Zainal Bakar untuk anak dan koleganya.

Keterlibatan pengusaha dalam aktivitas pertambangan liar memperlihatkan bahwa tidak bisa ditarik garis lurus yang membatasi antara rakyat, pengusaha dan Negara. Rakyat yang tidak memiliki modal sangat mungkin melakukan penambangan liar atau PETI karena minim modal untuk melakukan pertambangan resmi atau melakukan usaha yang sustainable. Pengusaha yang memiliki modal sementara itu ternyata juga menjalankan pertambangan liar dengan menjadi 'cukong' bagi masyarakat yang melakukan penambangan liar. Cukong menjadi kecemasan tersendiri karena bila aktivitasnya terus berlangsung, besar kemungkinan akan terjadi penguasaan lahan tambang oleh pihakyang tidak memiliki izin ini (Singgalang, 1999).

Bagaimanapun, perlu dilihat sisi lain dari aktivitas para cukong ini. Dengan menjadi penadah bagi 'hasil tambang' masyarakat, mereka justru memberi kesempatan bagi masyarakat untuk ikut terlibat langsung dalam perekonomian. Kelemahannya lagi-lagi adalah, hal ini dilakukan secara tidak resmi sehingga berisiko bagi masyarakat dan dengan skema yang tidak sustainable bagi masyarakat secara ekonomi.

\section{Dari Tambang Negara ke Tambang Rakyat}

Dilihat sejak Indonesia merdeka, terutama sejak berlangsungnya Nasionalisasi tambang batu bara Ombilin- kehidupan dunia tambang sepertinya berjalan dengan normal saja. Kalaupun ada riak seperti kejadian politik tahun 1965-an, tidak banyak membawa pengaruh yang besar dalam dinamika tambang. Gejolak politik yang dilakukan oleh buruh tambang yang tergabung dalam PKI tidak berpengaruh tinggi, yang sampai mengganggu proses produksi dan jalannya perusahaan. Namun, sejak era reformasi tahun 1998 lalu, dinamika politik di tingat nasional berpengaruh kuat terhadap dunia tambang. Hal yang sangat menyolok terjadi adalah dominasi negara lebih dari satu abad menjadi rontok (Herman, 2005)

Sejak masuknya era reformasi, terjadi perubahan besar dalam dunia tambang batu bara Ombilin. Rakyat yang selama satu abad menjadi penonton dalam dunia tambang, kemudian langsung memasuki dunia ini. Areal tambang yang diklaim selama satu abad milik perusahaan tambang, sedikit demi sedikit beralih menjadi tambang rakyat. 
Dominasi tunggal negara dalam menambang batu bara Ombilin bergeser menjadi tambang rakyat. Hal ini ditandai dengan munculnya ratusan tambang di Sawahlunto. Kehadiran tambang rakyat membawa perubahan besar dalam kehidupan masyarakat Sawahlunto, terutama rakyat bisa menikmati manisnya uang batubara. (Zulqayyim dan Zubir,2006). Melihat perkembangan dunia tambang setelah era reformasi di Sawahlunto, setidaknya terdapat tiga penyebutan yang lazim dipakai, baik oleh masyarakat maupun pemerintah, yaitu tambang swasta, Tambang Liar, Tambang Tanpa Izin dan Tambang Rakyat. (Zulqayyim dan Zubir, 2006).

Sepanjang sejarah PT. Tambang batubara Ombilin, telah terjadi beberapa kali pergantian rezim. Rezim-rezim yang pernah berkuasa diantaranya; rezim Kolonial Belanda, rezim Jepang, rezim Orde lama, rezim Orde Baru dan rezim Orde Reformasi. Dalam setiap pergantian rezim, kelihatannya tidak mengalami perubahan yang radikal, kecuali pada masa dari rezim Orde Baru ke rezim reformasi yaitu bertukarnya tuan tambang dari negara ke rakyat.

Nasionalisasi perusahaan tambang batu bara Ombilin sesungguhnya sudah terjadi sejak Indonesia merdeka tahun 1945. Setelah Jepang kalah, tambang batu bara Ombilin langsung dikuasai oleh orang Indonesia. Berbeda dengan perusahaan lainnya di Indonesia, yang pengambilalihannya melalui proses nasisonalisasi (Muhaimin, 1991:173). ternyata tambang batu bara Ombilin tidaklah melalui jalan berliku yang demikian itu. Proses nasionalisasi pada TBO tidak berjalan sebagaimana proses nasionalisasi yang dialami oleh perusahaan-perusahaan lain melalui nasisonalisasi, akan tetapi TBO secara langsung dikuasai oleh bangsa Indonesia. Dapat dikatakan bahwa proses nasionalisasi tidak ada di TBO (Zubir, 2006).

Jika mau melihat persoalan nasionalisasi tambang, justru yang perlu diperhatikan adalah ketika kolonial Belanda melakukan konsesi dengan penghulu di tahun 1891-an. Memang, pada masa itu sudah ada upacara adat untuk membebaskan tanah tambang, namun jumlah tanah yang diberi hak konsesi itu tidak lah seluas dengan yang ditambang selanjutnya (Zubir, 2006). Di banyak lokasi, Belanda menambang batubara di luar tanah konsesi, sehingga kemudian banyak tanah ulayat yang dicaplok. Persoalan warisan Belanda dalam pengambilan hak tanah ulayat yang ditambang. Artinya, proses nasionalaisasi yang terjadi pada tambang batu bara belum menyentuh akar persoalan yaitu masalah tanah areal tambang. Dengan demikian, pertanyaan utama dari tulisan ini adalah Setelah terjadi nasionalisasi pada Perusahan tambang batu batu Ombilin tahun 1945, bagaimana kah warisan persoalan yang di tinggalkannya?

Satu hal yang jelas, warisan persoalan utama adalah masalah tanah ulayat. Tanah ulayatnya diambil oleh perusahaan, tanpa ganti rugi yang memadai. Di sini muncul persoalan mendasar yaitu pola pemilikan tanah. Dalam masyarakat Minangkabau tanah adalah salah satu sumber ekonomi yang penting. Tanah tersebut biasanya dimiliki oleh kaum perempuan (bundo kanduang) yang bersifat turun temurun. Dalam hal status tanah terdiri dari tanah pusaka, tanah suku/adat dan tanah ulayat tersebut dikelola oleh kaum adat dan tokoh masyarakat. Polemik antara PT. MM dengan PT. Batubara Ombilin Bukit Asam menyangkut persoalan tanah ulayat ini. (Zubir, 2001).

Persoalan PT. BATUBARA OMBILIN Bukit Asam dengan PT. MM mencuat kepermukaan. Kapolda Sumbar, Adang Firman, dalam sebuah wawancara tanggal 25 September 2001 dengan wartawan menyatakan bahwa ; konflik antara PT. Minang Malindo (PT MM) dengan PT Bukit Asam Unit Pertambangan Ombilin (PT. BA-UPO) ibarat "api dalam sekam," yang setiap saat bisa meledak. Dari pernyataan di atas menarik untuk dikaji, kenapa PT. MM yang baru berumur 5 bulan itu bisa mengalami konflik yang tajam dengan PT. Batubara Ombilin-UPO yang telah beroperasi 
lebih dari satu abad (Surat kabar Haluan, 25 September 2001.

Era reformasi sesungguhnya membawa perubahan besar dalam tatanan masyarakat di Indonesia. Berbagai perubahan yang terjadi, dan kesempatan bagi setiap orang untuk hidup lebih bebas dan merdeka menjadikan banyak kesempatan bagi masyarakat untuk memperbaiki kehidupannya. Hal ini terlihat pada masyarakat di kota tambang yaitu Sawahlunto di Sumatera Barat.

Pada kota tambang ini, dapat dikatakan bahwa lebih dari satu abad masyarakat-penduduk asli setempat- hanyalah sebagai penonton dari pengerukan kekayaan alam mereka. Jika dahulu yang mengeruk kekayaan adalah pemerintah kolonial Belanda, maka separoh abad terakhir ini adalah pemerintah bangsa sendiri. Namun, masyarakat tidak memiliki daya dan upaya untuk dapat menikmati kekayaan alam di tanah air mereka sendiri. Kalaupun ada masyarakat sekitar yang menikmati, mereka hanyalah sebagai buruh kasar, sehingga tingkat kesejahteraannya pun rendah. Perubahan besar terjadi sejak era reformasi, dimana masyarakat memiliki kesempatan untuk menikmati hasil alam mereka sendiri.

Keterlibatan rakyat di kota tambang ini dalam dunia tambang juga menjadi fenomena sendiri. Bisnis ini juga membutuhkan modal besar -terutama batu bara-, sehingga ketika membutuhkan modal, kembali masyarakat dihadapkan pada persoalan lama yaitu berhadapan dengan modal. Pada masyarakat kota tambang ini, setelah 60 tahun merdeka, setelah lebih satu abad penguasa dan pengusaha mengeruk kekayaan alam mereka, maka sejak era reformasi inilah mereka baru dapat merasakan manisnya uang dari kekayaan alam mereka sendiri. Di Sawahlunto, mau dibawa kemana batu bara itu, semua pemasaran dikuasai oleh pemerintah. Sekarang ini setiap orang bisa saja menambang dan mencari pasaran sendiri, untuk memperjuangkan nasib anak dan istrinya ataupun sekedar bertahan hidup.

\section{Kesimpulan dan Saran}

Melihat peta persoalan perusahaan negara di banyak tempat, sudah seharusnya berbagai persoalan besar yang dipeti-es-kan selama ini dibuka sebagai sebuah persoalan bersama, terutama masalah hak atas tanah. Seperti kasus batu bara Ombilin, pemakaian tanah ulayat yang melebihi dari konsesi yang diberikan, ledakannya justru terjadi setelah satu abad lebih batu bara itu beroperasi. Pada hal, jika dibenahi dari awal, maka konflik dan kekerasan tidak harus terjadi, karena setiap orang yang berada di sekitar perusahaan itu mendapatkan hak-haknya, sesuai dengan kerugian yang digantikan oleh perusahaan. Jika ini tidak diselesaikan secara lebih bijak, maka bibit-bibit kekerasan itu akan meledak di berbagai pelosok.

Kekerasan itu menjadi hal yang tidak dapat dielakkan. Kapling-kapling tanah terjadi begitu saja di wilayah konsesi milik PT. Tambang Batu Bara Ombilin. Kekuatan rakyat dalam jumlah yang besar mejadi hal yang tidak bisa dilawan oleh pihak tambang, sehingga sedikit demi sedikit tambang rakyat itu menggerogoti tanah dan kekuasaan tambang, yang pada akhirnya rontok. PT. Batubara Ombilin yang dominan lebih satu abad kemudian hanyalah menjadi penampung hasil tambang rakyat dan kemudian dijualnya pembangkit tenaga listrik di Sawah Rasau Sawahluto. Semen Padang yang selama satu abad menjadi pembeli batu bara dati PT. Batubara Ombilin, kemudian mengalihkan kepada pemasok lain terutama dari berbagai PT-PT yang tumbuh berkembang selama masa reformasi. Bahkan, dalam satu polemik antara PT. Batubara Ombilin dengan PT Semen Padang tentang jual beli batu bara, PT. Batubara Ombilin menuduh PT Semen Padang sebagai penadah barang curian, karena PT. Batubara Ombilin beranggapan bahwa hasil batu bara yang dijual ke PT. Semen Padang itu merupakan barang jarahan dari batu bara milik PT. BATUBARA OMBILIN.

Pengalaman dari rontoknya PT. Batubara Ombilin mengajarkan kepada kita bahwa 
pendekatan keamanan yang dilakukan selama masa Orde Baru dalam mengurus negara sesungguhnya hanya bertahan dalam waktu singkat. Rontoknya rezim berkuasa juga diikuti dengan rontoknya bangunan kekuasaan yang dibuatnya sehingga berbagai usaha seperti eksploitasi tambang juga berakhir. Untuk menghindari hal demikian, maka ada beberapa pikiran utama sebagai saran yang harus menjadi bahan pertimbangan seperti;

1. Jangan dijadikan masyarakat sekitar tambang ataupun pembangunan sebagai penonton dari proyek yang sedang dilakukan.

2. Menjadikan masyarakat setempat sebagai bagian yang integral dari proyek pembangunan yang sedang dilakukan, sehingga mereka bisa beranggapan bahwa tempat kerjanya sebagai rumah mereka sendiri.

3. Selama mereka bisa menjadi bagian dari perusahaan, tentu juga diikuti pemberian hak-hak yang tidak berbeda dengan lainnya, sesuai dengan tingkatan kerja masingmasing, maka mereka sudah menjadi modal besar untuk mencegah konflik kekerasan terhadap perusahaan.

4. Selama hal itu dilakukan, maka keresahan, kekerasan dan sampai tindakan anarkis akan dengan mudah bisa dicegah, karena dalam tubuh perusahaan sudah ada putra asli daerah yang menjadi bagian integral, yang akan dapat membendung berbagai tindakan kekerasan yang datang dari masyarakat sekitarnya.

\section{Daftar Pustaka}

Alfian (ed), 1986. Kemiskinan Struktural. Jakarta : YISS.

Booth, Anne (eds.), 1988. Sejarah Ekonomi Indonesia. Jakarta : LP3ES.

Burke, Peter. 1992. History and social Theory. Cambridge, Polity Press.

Chambers, R. 1987. Pembangunan Desa : Dimulai Dari Belakang. Jakarta : LP3ES.
Erman, Erwiza, 1999. "Miners, Managers and the State: A Socio-Political History of the Ombilin Coal-Mines, West Sumatra 1892-1996". Ph.D. Disertation. University Amsterdam.

2004. "Illegal Mining in West Sumatra: Access, Actors, and Agencies In the Post Suharto-era". Makalah, 2 Agustus.

Fakih, Mansour, 2001. Runtuhnya Teori Pembangunan dan Globalisasi. Yogyakarta : Insist Press.

Geertz. C., 1989. Penjaja dan Raja : Perubahan Sosial dan Modernisasi Ekonomi di Dua Kota Indonesia. Jakarta : Yayasan Obor Indonesia.

Kartodirodjo, Sartono, 1983. Elite Dalam Perspektif Sejarah. Jakarta : LP3ES. 1992. Pendekatan Ilmu-ilmu Sosial Dalam Metodologi Sejarah. Jakarta : PT Gramedia.

Kuntowidjojo, 1993. Metodologi Sejarah. Yogyakarta : Tiara Wacana.

Legg, Keith R, 1983. Tuan, Hamba dan Politisi. Jakarta : Sinar Harapan.

Lindblad, J. Thomas, (ed), 2000. Fondasi Historis Ekonomi Indonesia.Yogyakarta : Pustaka Pelajar.

Moleong, Lexy J., 1993. Metode Penelitian Kualitatif. Bandung : Remaja Rosda.

Muhadjir, Noeng, 2000. Metode Penelitian Kualitatif. Yogyakarta : Penerbit Rake Sarasin.

Muhaimin, Yahya A., 1991. Bisnis dan Politik: Kebijaksanaan Ekonomi Indonesia 19501980. Jakarta : LP3ES.

Nas, P.J.M. (eds.), 2004. The Indonesian City. Dordrecht: Foris Publications.

Navis, A.A., 1986. Alam Terkembang Jadi Guru. Jakarta : PT Grafiti Press.

Singh, Rejendra, 2004. Social Movements : Old and New. New Delhi : Sage Publications 
Sjoberg, Gideon, 1996. The Pre-industri City: Past and Present. New York: The Free Press.

Sunardi, Adeng, 1991.100 Tahun Tambang Baru Bara Ombilin. Sawah Lunto : Tanpa Penerbit.

Wie, Thee Kian,1991. Pemerataan, Kemiskinan, Ketimpangan. Jakarta : Sinar Harapan.

Weber, Max, 1999. Etika Protestan dan Spirit Kapitalisme. Jakarta : Pustaka Pramathea.

Zubir, Zaiyardam 2006. Pertempuran Nan Tak Kunjung Usai. Padang : Andalas University Press.

(dkk), 2005. Sawahlunto : Kemaren, Kini dan Esok. Padang : PSH Unand.

,2006. "Wajah Dua Kota Tambang : Sawahlunto dan Pangkal Pinang”, dalam,
Alfan Miko (ed), Dinamika Kota Tambang Sawahlunto, Dari Ekonomi Kapitalis ke Ekonomi Rakyat. Padang : Unand Press.

\section{Surat Kabar}

Surat kabar Haluan

Surat kabar Kompas

Surat kabar Tempo

Surat kabar Mimbar Minang

Surat Kabar Singgalang 
